\title{
Curriculum Planning of " Electronic Control Technology of Machine Tool " based on the Training Mode of Learning Ability
}

\author{
Zheng Xianying \\ Department of Mechanical Engineering, Dalian Vocational \& Technical College, Dalian, Liaoning, \\ 116037, China \\ 1054797289@qq.com
}

Keywords: Higher vocational education; learning ability; Curriculum planning

\begin{abstract}
The higher vocational education in our country has gradually shifted from the mere consideration of the employment rate of graduates to the employment quality and the future development of the vocational education. The ability to learn has become a bottleneck of the development of Higher Vocational students' prospects. In this paper, the author will sum up experiences of being a teacher and working in a factory, for the peculiarity of higher vocational students, and explore the process of teaching the course " electronic control technology of machine tool ".
\end{abstract}

\section{Introduction}

Learning ability generally refers to people's drive towards learning, hard work and self-improvement in formal or informal learning environments. It refers to the survivability of an individual in the society, their core competitiveness. Quoting former president of Fudan University professor Yang Fujia: "nowadays, by the day college students graduated from university, half of the knowledge they receive is already forgotten”. So the learning ability of student is an important factor of their future development and employment quality. The higher vocational education in our country has gradually shifted its focus from mere consideration of the employment rate of graduates to the employment quality and the future. As a result, stressing the importance of the development of one's learning ability becomes essential.

\section{Orientation of the Course "Electronic Control Technology of Machine Tool" in Higher Vocational Colleges}

Higher vocational education teaches professionals in the fields of production, serving and managing. Higher vocational students' prospects include front-line managers, front-line technical service personnel, and front-line intelligent operating personnel. electronic control technology of machine tool is a specialized lesson of the students majoring in Mechanical Design Manufacturing and Automation, its purpose is to enable students to master design methods of CNC Machines, primitive design, programming and debugging skills, and at the same time is a basic course of cultivating the ability of sustainable development.

\section{Higher Vocational Students Learning Situation}

Students Knowledge Base. At present, a certain degree of prejudice towards higher vocational education still exists in the society. According to the common bias, choosing an education in higher vocational college results in one's future prospects to being limited to labor occupations. Therefore higher vocational colleges have very low score requirement for potential students. As a result, students' basic education and comprehension ability tends to be of an overall low quality.

Learning Attitude. There is a common perception that higher vocational college students are lacking in terms of clear educational goals and are not planning their careers. Some of the students think after getting into the higher vocational school they no longer require to study as this will automatically result in a diploma that is sufficient to find a job. Others believe that their future is 
that of a worker, so one does not need to improve one's self, merely meet the minimum requirements.

Learning Ability. Learning ability includes learning autonomy, learning initiative, one's confidence and ability to innovate, not only it contains active adjustment of one's own knowledge structure, but also the values and thinking mode of active innovation. Higher vocational college students did not develop good learning methods and learning attitude over the course of their previous studies, their learning autonomy, initiative, etc are overall weak. It is an impossible endeavor for a college to teach them every aspect of their course, thus students are expected to continue learning during work. As such the cultivation of one's ability to learn, is very important.

\section{Traditional Teaching Method of Electronic Control Technology of Machine Tool Course}

"Electronic control technology of machine tool" course is a strong and comprehensive discipline, involving the knowledge on different subjects such as basics of electrical and mechanical drives, sensors and so on. Teaching of the subject in the past was generally divided in 2 steps, first was to learn theory in detail and then complete a set of exercises at the end of each chapter. There are several problems with this method of teaching the material.

Students were Gradually Losing Interest in Learning. The course "electronic control technology of machine tool" is highly consistent and requires a lot of practice. Because of students' lack of good basic theoretical knowledge, they oftentimes fall into a bad psychological cycle where a student is afraid of difficult topics, which leads them into having lower level of knowledge. In class, students interest towards the subject gradually reduce, which leads to learning difficulties, resulting in students aim to just pass the exam.

Results of Studies are not Obvious. Our country present training conditions are lacking, situations where during practice students do not have enough teachers. Oftentimes a class of around 30 students is only being assisted by 1-2 teachers. It is difficult for the students to start experimenting right after learning the theory and they are often just mechanically imitating the teacher. The knowledge students receive is shallow. Due to the differences between the knowledge levels of students, if a teacher makes students complete their projects by themselves, many will not be able to complete them. Thusly a 40 minutes course will not be efficiently used and the results of the subpar practice will not allow students' skills to make a major improvement.

The Learning Ability of Students can't Substantially Improve. From the above 2 points, we discovered that the students just passively accept the study process. As a result, the teacher must play a role of a leader in the teaching process and proactively pass their knowledge onto the students, rather than allowing the students to figure out their own ways of solving problems. While the learning initiative, creativity and independence remains lacking, the learning ability of students can't be substantially increased.

\section{The Teaching Method of Cultivating the Ability of Learning}

In the beginning, post graduate students in general start as "silver collar", after a period of time, students need to improve their skills, and so the whole teaching process should be re-designed on the basis of acquiring practical knowledge and be in general more practice-oriented. In order to achieve that, breaking of the traditional subject system is required in order to use the knowledge gained through the whole course. Furthermore a certain level of attention should be put into the design of every class so as to try to cultivate the students' learning initiative, autonomous learning ability, etc. In the process of learning aside from acquiring theoretical and practical knowledge, students should be stimulated to cultivate creativity, and obtain the competence and character traits necessary to work in the future, such as the will, a quality, etc. Below is the example lesson featuring Mitsubishi PLC input/output relay that explains how to cultivate the students' learning ability throughout teaching process.

Details are shown in Table 1. Familiarity with internal components of PLC is the basic knowledge of PLC. In the past, in order to teach the PLC lesson, the teacher would explain the 
internal components, but the explanation would always be is in accordance with the manufacturer's manual explains some conceptual stuff, four internal components commonly 4 classes, and then doing the experiment, integrated operation is needed to do experiment. As a result, effects of this method of teaching are not ideal, but due to the limited class hours, impossible to get enough practice. According to author's factory and teaching experience, puts forward PLC study commonness, adjust teaching way, do it step by step in teaching penetration ability in learning.

\begin{tabular}{|c|c|c|c|}
\hline & \multirow{2}{*}{\multicolumn{2}{|c|}{$\begin{array}{l}\text { content } \\
\text { the PLC internal components - input/output relay and its } \\
\text { application }\end{array}$}} & Remark \\
\hline title & & & $\begin{array}{l}\text { Dividing the PLC internal } \\
\text { components to several parts to teach }\end{array}$ \\
\hline Import & \multicolumn{2}{|c|}{$\begin{array}{l}\text { Staring with using PC as an example, let students find } \\
\text { out if mouse, keyboard and printer are the input or } \\
\text { output part of a PC, leading to the content of the course. }\end{array}$} & $\begin{array}{l}\text { Making students interested in this } \\
\text { lesson (Students are familiar with } \\
\text { computers). }\end{array}$ \\
\hline $\begin{array}{l}\text { theory } \\
\text { explanation }\end{array}$ & \multicolumn{2}{|c|}{$\begin{array}{l}\text { 1. PLC should be connected to the equipment via } \\
\text { input/output interface, while software takes } \\
\text { responsibility for the logic. (Using printer driver as an } \\
\text { example) } \\
\text { 2. The interpretation of input and output relay } \\
\text { 1)address: octonary and hexadecimal addresses' } \\
\text { common use } \\
\text { 2)the function of input relay: identify the state of the } \\
\text { input of PLC through attachment, that is, the logic of } \\
\text { PLC internal relay input contact is consistent with the } \\
\text { logic of input contact } \\
\text { 3)the function output relay: connect the output of the } \\
\text { PLC to control equipment through attachment, that is, } \\
\text { the logic of PLC internal output relay coil is } \\
\text { consistent with the logic of load component, then you } \\
\text { can control output relay through software }\end{array}$} & $\begin{array}{l}\text { Completing teaching the basic } \\
\text { theoretical knowledge, enough for } \\
\text { current class }\end{array}$ \\
\hline \multirow{5}{*}{$\begin{array}{l}\text { Classroom } \\
\text { training }\end{array}$} & $\begin{array}{l}\text { PLC } \\
\text { peripheral } \\
\text { wiring }\end{array}$ & 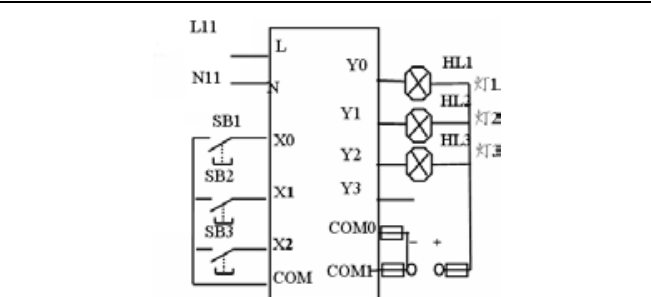 & $\begin{array}{l}\text { Cultivating students' familiarity } \\
\text { with wiring of PLCs }\end{array}$ \\
\hline & \multirow{4}{*}{$\begin{array}{l}\text { The input } \\
\text { of the } \\
\text { program }\end{array}$} & $\begin{array}{l}\text { 1)a simple input program, which the first } \\
\text { button control the first light, the second } \\
\text { button control the second light, the third } \\
\text { button to control the third light }\end{array}$ & $\begin{array}{l}\text { First questions are relatively easy in } \\
\text { order to increase the students' } \\
\text { confidence. }\end{array}$ \\
\hline & & 2)methods of debugging & $\begin{array}{l}\text { Familiarity with another important } \\
\text { topic on PLCs. It can also be } \\
\text { connect with the practice in factory }\end{array}$ \\
\hline & & $\begin{array}{l}\text { 3)without changing the program, make the } \\
\text { first button control the second light, the } \\
\text { second button control third light, the third } \\
\text { button to control the first light by only } \\
\text { change the hardware connection. } \\
\text { 4)not change wiring, do the question } 1 \\
\text { again. }\end{array}$ & Cultivating the students' initiative \\
\hline & & $\begin{array}{l}\text { 5)set the question again, after giving } \\
\text { electricity, the system failed, log the } \\
\text { problem phenomenon, describe and write } \\
\text { down the debug progress. }\end{array}$ & $\begin{array}{l}\text { Cultivate the students' ability to } \\
\text { analyze and solve problems and } \\
\text { innovate, thus rewarding students } \\
\text { with a sense of achievement. }\end{array}$ \\
\hline
\end{tabular}


This class is based on the principle of mixing theory and practice together. In the design of the course, author was using the principle "sufficient is fine", by finding the important points of PLC and gradually deepening the knowledge over course of each lesson. For the practice of input output relay, first we get student's interest by making them solve easy problems, then we let students independent thinking by a simple problems we may encounter in the factory(question 3.4), in the end, we cultivate student's self-learning ability by assigning them homework which requires students to search for extra information in order to finish. By using this method, this PLC course teaching is based on, we cultivate students' learning ability during the entire process in order to achieve a good results.

\section{Conclusion}

As a result, teachers should pay attention to the students' independent thinking during class, the teacher's involvement needs to be gradually decrease, we should also take the students as the main focus, cultivate students' autonomous learning ability, advocate independent and cooperative learning and inquisitively, so that students can get a solid foundation for their future career development.

\section{References}

[1] Dayuan Jiang. New Discussion on vocational Education[M].Beijing: Education science Press,2007.

[2] Hui Sun, Guojian Zhang. Vocational students' sustainable development ability construction of teaching system [J]. Science times, 2009(2).

[3] Jingxia Lian. Review of Core Competency in China Vocational Education [J]. Vocational Education Research,2012,3:16 17.

[4] Pingan Wang. Introduction to vocational education practical teaching [M].Nanjing: Nanjing university Press,2009.

[5] Lan Ye. The pedagogy principle [M].Beijing: People's education press,2007.

[6] Chunsheng Liu, Changfa Xu. education pedagogy, [M].Beijing: Education science press,2002

[7] Zhengxing Wang. University students' employment difficult reason and analysis [J]. modern Vocational Education,2015,10:106 107. 